\title{
Phosphorus cycling in primary and secondary seasonally dry tropical forests in Mexico
}

\author{
Patricia VAldeSPINO ${ }^{1}$, Rigoberto RoMUALdo ${ }^{1}$, Laura CADENAZZI ${ }^{1,2}$, Julio CAMPo ${ }^{1 *}$ \\ ${ }^{1}$ Instituto de Ecología, Universidad Nacional Autónoma de México, AP 70-275, 04510 México, D.F., México \\ ${ }^{2}$ Facultad de Ciencias, Universidad de la República, Montevideo, Uruguay
}

Keywords:

litter and litterfall /

secondary succession /

$P$ availability /

tropical soils

(Received 23 January 2008; accepted 5 October 2008)

Mots-clés :

litière /

succession secondaire / disponibilité du phosphore / sols tropicaux

\begin{abstract}
- Primary forests in the seasonally dry tropical regions of Mexico are disappearing under land-use pressure, creating a mosaic of secondary forests of different ages.

- In this study we measured the aboveground litterfall phosphorus (P) fluxes, litter-layer and soil P pools to compare the $\mathrm{P}$ cycles in primary and secondary seasonally dry tropical forests. Our hypothesis was that the previous agricultural land use of secondary forests would bring about a lower P flux in the litterfall, lower soil $\mathrm{P}$ pool, and higher nutrient resorption proficiency than in primary forests, as well as an increase of relative amounts of available P provided by the soil with forest aging.

- The expected litterfall P flux increase in the secondary forest following a previous agricultural land use did not occur. Phosphorus return to the soil by aboveground litterfall was unaffected by the succession stage of the forest. In addition, the total soil $\mathrm{P}$ pool did not change with forest age. However, available soil P (bicarbonate P-inorganic and P-organic pools) and hydroxide inorganic P pools were higher in primary than in secondary forest soils. Phosphorus concentration in litterfall increased significantly with forest age, suggesting that $\mathrm{P}$ is cycled more efficiently (by a higher nutrient resorption proficiency) when soil available $\mathrm{P}$ is less abundant. Despite these differences among forests, the results of our study gave evidence that $\mathrm{P}$ requirements by plants in primary and secondary forests are sufficiently met by the accumulation of dissolved (water extractable) $\mathrm{P}$ in the forest floor during the dry season and by soil bicarbonate-P pools.

- Our study on the effects of land cover change on P cycling, following the discontinuation of agricultural practices, leads to the conclusion that this ecosystem $\mathrm{P}$ dynamics will vary depending on the successional stage of the forests, and is strongly influenced by the seasonal rainfall pattern which determines plant-available $\mathrm{P}$.
\end{abstract}

Résumé - Cycle du phosphore dans les forêts primaires et secondaires tropicales à saison sèche du Mexique.

- Les forêts primaires dans les régions tropicales à saison sèche du Mexique sont en train de disparaître sous la pression de l'utilisation agricole des terres, créant une mosaïque de forêts secondaires d'âges différents.

- Dans cette étude, nous avons mesuré les flux de phosphore $(\mathrm{P})$ de la litière au-dessus du sol, de l'horizon de litière et les pools de phosphore $\mathrm{P}$ du sol, pour comparer les cycles de $\mathrm{P}$ dans les forêts primaires et secondaires tropicales à saison sèche. Notre hypothèse est que l'exploitation agricole précédente des forêts secondaires devrait aboutir à un flux plus faible de $\mathrm{P}$ dans la litière, à un plus faible pool de $\mathrm{P}$ du sol, et à une résorption plus élevée des éléments nutritifs que dans les forêts primaires, ainsi qu'une augmentation des quantités relatives de $\mathrm{P}$ disponibles fournies par le sol avec le vieillissement de la forêt.

- L'accroissement attendu du flux de $\mathrm{P}$ par la litière dans la forêt secondaire, suite à un précédent usage agricole des terres, n'a pas eu lieu. Le retour du phosphore à la surface du sol par la litière n'a pas été affecté par la succession des stades de la forêt. En outre, le pool total de phosphore n'a pas changé avec l'âge des forêts. Toutefois, $\mathrm{P}$ disponible dans le sol (pools de bicarbonate P-inorganique

\footnotetext{
*Corresponding author: jcampo@ecologia.unam.mx
} 
et P-organique) et les pools d'hydroxyde de $\mathrm{P}$ inorganique étaient plus élevés dans les sols forestiers des forêts primaires que dans les sols forestiers des forêts secondaires. La concentration de phosphore dans la litière a augmenté de manière significative avec l'âge des forêts, ce qui suggère que $\mathrm{P}$ est recyclé de manière plus efficace (par une plus grande maîtrise de la résorption des éléments nutritifs) quand $\mathrm{P}$ disponible dans le sol est moins abondant. En dépit de ces différences entre les forêts, les résultats de notre étude ont donné la preuve que les exigences de $\mathrm{P}$ par les plants dans les forêts primaires et secondaires sont suffisamment remplies par l'accumulation ou la dissolution (extractibles par l'eau) de $\mathrm{P}$ dans la couverture du sol pendant la saison sèche et par le bicarbonate-P du sol.

- Notre étude sur les effets du changement de la couverture du sol sur le cycle de $\mathrm{P}$, à la suite de l'abandon des pratiques agricoles, conduit à la conclusion que cette dynamique de $\mathrm{P}$ dans l'écosystème varie selon le stade de succession des forêts, et est fortement influencée par la pluviométrie saisonnière qui détermine le $\mathrm{P}$ disponible pour les plants.

Abbreviations: SDTF seasonally dry tropical forest; PMF, primary forest; ESF, early successional forest; MSF, mid-successional forest; LSF, late-successional forest;

\section{INTRODUCTION}

Primary forests in seasonally dry-tropical regions have undergone intense land use change, ranging from widespread shifting cultivation agriculture to land clearing for cattle range. The subsequent land use abandonment is common, and leads to the formation of a primary forest - pastures -, a secondary forest mosaic throughout the landscape. Agricultural activities have brought about fundamental changes in the carbon and nutrient pools and fluxes that originally existed in native forests (Giardina et al., 2000; Maass, 1995; McLauchlan, 2006). Therefore a major goal in assessing environmental change is to understand how biogeochemical processes respond to land change, emphasizing a man-dominated landscape potential to sustain continuous human use. Secondary seasonally dry tropical forests (SDTF) are usually fast-growing ecosystems (Brown and Lugo, 1990). However, for a successful management and forest regeneration of plains, it is first necessary to learn about their nutrient cycles, soil conditions and soil fertility changes before and after the discontinuation of agricultural practices.

There are few studies on the biogeochemical processes of the SDTF secondary succession. The evidence indicates that secondary SDTFs play an important role in global carbon dynamics due to their high rates of growth and nutrient turnover compared to mature forests (Brown and Lugo, 1990; Read and Lawrence, 2003). The factors regulating SDTF productivity indicate that soil nutrient availability, particularly phosphorus $(\mathrm{P})$, limits the primary production of secondary forests in Yucatán limestone soils (Campo and Vázquez-Yanes, 2004). In addition to such phenomenon, other processes like herbivory density (Campo and Dirzo, 2003) and the activity of soil microbial biomass (Solís and Campo, 2004) may also be influenced by an herbivore or microbial response to variations in $\mathrm{P}$ availability. A high P-resorption proficiency (sensu Killinbeck, 1996) by plants during secondary succession on volcanic soils in central Mexico (Cárdenas and Campo, 2007) suggests that $\mathrm{P}$ could play a key role in the primary production of other SDTFs.

Though SDTFs represent $\sim 42 \%$ of all tropical forest vegetation (Murphy and Lugo, 1986) in relation to moist forests, the biogeochemistry of dry forests has received little attention. There are few studies on SDTF nutrient cycling, most of them about mature forests (Campo et al., 2000; 2001); in these P vegetation requirements are largely met by within-ecosystem recycling mechanisms. It is generally believed that the decomposition of surface litter and the accumulation of dissolved forms of nutrients are the most important mechanisms to supply plant available P (Campo et al., 1998; 2001). Although Read and Lawrence (2003) and Campo et al. (2007) reported about the rates of litterfall $\mathrm{P}$ fluxes in SDTFs during secondary succession, none of these studies included an evaluation of $\mathrm{P}$ dynamics in the forest soil, which suggests a lack of information about $\mathrm{P}$ cycling during forest aggradations.

In this study, aboveground litterfall and their P concentration, litter layer $\mathrm{P}$ content, and soil $\mathrm{P}$ fractions were measured to compare $\mathrm{P}$ cycles (i.e., the intrasystem cycling) in primary and secondary SDTFs. Specifically, we used these data to (1) quantify the amounts of litterfall $\mathrm{P}$ fluxes that return to the soil, (2) assess the relationship between the available soil $\mathrm{P}$ and nutrient proficiency for plants, and (3) examine the relationship between the available soil $\mathrm{P}$ and soil $\mathrm{P}$ requirement for aboveground production. We thought litterfall $\mathrm{P}$ flux to be lower in the early stages of forest succession and increase with forest age; that soil P pools would register a decrease and nutrient proficiency would be higher in the secondary forest sites than in mature forests. Another expectation we had in mind was an increase in the relative amounts of $P$ provided by the soil with respect to the $\mathrm{P}$ required by plants with forest aging. To study the P cycling, we selected sixteen forests stands in Morelos, Mexico. These included four primary forest stands, and four secondary forest stands of each early-successional, mid-successional and late-successional stage. In a prior study on these stands, Saynes et al. (2005) concluded the following: (1) soil organic $\mathrm{C}$ does not change with the forest stage; (2) soil total and inorganic $\mathrm{N}$ are higher in the early- and midsuccessional forests than in the primary forest stands (increasing the $\mathrm{C}: \mathrm{N}$ ratio), as well as the potential $\mathrm{N}$ mineralization and nitrification; (3) in late-successional soils, $\mathrm{N}$ pools do not differ from those of the early- and mid-successional soils, but potential $\mathrm{N}$ transformations in late-successional soils are lower than in mid-successional soils (see Tab. I). 
Table I. Site characteristics ( \pm standard error) for different seasonally dry tropical forests studied at Sierra de Huautla, Mexico.

\begin{tabular}{|c|c|c|c|c|}
\hline & \multicolumn{4}{|c|}{ Forests } \\
\hline Time since forest recovery $(\mathrm{y})$ & & 10 & 30 & $\sim 60$ \\
\hline Basal area $\left(\mathrm{m}^{2} \mathrm{ha}^{-1}\right)$ & $16.5(1.4)$ & $8.5(1.1)$ & $9.7(1.0)$ & $12.8(1.2)$ \\
\hline Tree density $\left(\right.$ stems ha ${ }^{-1}$ ) & $2153(377)$ & $2049(293)$ & $1938(322)$ & $2023(215)$ \\
\hline Tree height (m) & $7.8(0.7)$ & $4.1(0.5)$ & $5.7(0.6)$ & $5.9(0.5)$ \\
\hline $\mathrm{pH}\left(\mathrm{H}_{2} \mathrm{O}\right)$ & $7.3(0.1)$ & $7.2(0.1)$ & $7.1(0.1)$ & $7.1(0.1)$ \\
\hline Organic $\mathrm{C}(\mathrm{Mg} \mathrm{C} \mathrm{ha-1})$ & $38.3(6.6)$ & $36.7(8.9)$ & $41.1(5.4)$ & $43.6(6.3)$ \\
\hline $\mathrm{N}-\mathrm{NH}_{4}\left(\mathrm{~kg} \mathrm{ha}^{-1}\right)$ & $35(17)$ & $68(10)$ & $87(3)$ & $67(11)$ \\
\hline $\mathrm{N}-\mathrm{NO}_{3}\left(\mathrm{~kg} \mathrm{ha}^{-1}\right)$ & $2(1)$ & $3(1)$ & $5(1)$ & $3(1)$ \\
\hline Potential $\mathrm{N}$ mineralization $\left(\mathrm{kg} \mathrm{ha}^{-1} \mathrm{~d}^{-1}\right)$ & $23(8)$ & $53(6)$ & $80(5)$ & $45(4)$ \\
\hline Potential nitrification $\left(\mathrm{kg} \mathrm{ha}^{-1} \mathrm{~d}^{-1}\right)$ & $23(7)$ & $53(6)$ & $80(1)$ & $46(5)$ \\
\hline
\end{tabular}

${ }^{1}$ For all trees at least $2.5 \mathrm{~cm}$ in diameter at the start of the study.

${ }^{2}$ Data for 0-10 cm soil depth (Saynes et al., 2005).

\section{MATERIALS AND METHODS}

\subsection{Study areas}

The study was conducted at the Sierra de Huautla Reserve $\left(18^{\circ}\right.$ $28^{\prime} \mathrm{N}, 99^{\circ} 01^{\prime} \mathrm{W}$ ), in Morelos (Mexico). The site was chosen after assessing it as representative of land use in Mexico. The production system includes the extraction of timber and non-timber products from primary forest and slash-and-burn agriculture (milpa) with no chemical inputs. Native vegetation in the region is described as SDTF (sensu Mooney et al., 1995), but much of the land has been converted into secondary forest through the process of shifting cultivation. Soils are predominantly Entisols derived from granite rocks. Mean annual temperature is $24.5{ }^{\circ} \mathrm{C}$, with less than $4{ }^{\circ} \mathrm{C}$ difference between the coolest and warmest months. Mean total rainfall amounts to $851 \mathrm{~mm}$ (Comisión Nacional del Agua, personal communication), most of it falling between June and October ( $\sim 90 \%$ of the annual total).

In a continuous mosaic of primary and secondary seasonal forest, four stands of primary forest (PMF), and four of each earlysuccessional (10-15-year-old; ESF), mid-successional (20-30-yearold; MSF) and late-successional ( 60-year-old; LSF) forests were selected. All forest stands were 2-km away from each other, as described by Saynes et al. (2005). The sites in the chronosequence are at the same altitude ( 930 $\mathrm{m}$ a.s.l.), and have approximately the same relief (steep mountain).

In June and July 2001, a $12 \mathrm{~m} \times 12 \mathrm{~m}$ plot was set in each forest area. The primary forest had the largest basal area (Tab. I). Among secondary forests, basal area increases along a series from earlythrough mid-successional to late-successional forests.

\subsection{Determination of phosphorus flux in litterfall}

Phosphorus fluxes were calculated by multiplying the mass of litterfall by its nutrient concentration. Production data were obtained from five randomly located litter traps $(50 \mathrm{~cm}$ diameter $)$ in each one of the previously described plots. Litterfall was collected at approximately monthly intervals from June 2001 to May 2002. Phosphorus concentrations were determined monthly. The dry masses of litterfall and $\mathrm{P}$ content were measured. Mean litterfall mass and its nutrient content in each forest stage were calculated for samples from four plots (samples were composite by sampling date and plot).

\subsection{Determination of phosphorus pools in litter}

Dissolved (water-extractable) and total-P contents in litter were determined. Phosphorus pools were calculated by multiplying the litter mass by its nutrient concentration. Forest litter in the plot of each forest was sampled halfway through the rainy season (August 2001), at the beginning of the dry season (November 2001), midway through the dry season (February 2002), and starting the rainy season (May 2002), using a circular plot (0.2 $\mathrm{m}$ in diameter). Four samples were regularly collected within the $10 \mathrm{~m} \times 10 \mathrm{~m}$ central area of each plot on each sampling date. Litter samples consisted of all dead plant material lying on the forest floor, including the freshly fallen litter and the more finely decomposed litter fraction.

Undried subsamples of 0.15 -g litter were placed separately in $50-\mathrm{cm}^{3}$ centrifuge tubes. Thirty milliliters of deionized water were added to all tubes, shaken for $1 \mathrm{~h}$, and then centrifuged at $10000 \mathrm{rpm}$, and $0{ }^{\circ} \mathrm{C}$ for $10 \mathrm{~min}$. The supernatant was filtered through a Millipore filter $(0.45 \mu \mathrm{m})$; one aliquot of the filtrate was used to determine dissolved $\mathrm{P}$ in water extracts. A second litter subsample was extracted with hot concentrated $\mathrm{H}_{2} \mathrm{SO}_{4}$ plus $\mathrm{H}_{2} \mathrm{O}_{2}$ solution (total $\mathrm{P}$; see below Chemical Analysis). Mean P pools (i.e. dissolved and total) in litter were calculated for each forest stage (four plots) on each sampling date.

\subsection{Phosphorus pools in soil}

Soils of each forest site were sampled twice to determine the size of $\mathrm{P}$ pools (upper $0.2 \mathrm{~m}$ of the profile), during both the rainy season 
Table II. Means ( \pm standard error) of litterfall mass and P concentrations and fluxes for different seasonally dry tropical forests studied at Sierra de Huautla, Mexico.

\begin{tabular}{|c|c|c|c|c|}
\hline & \multicolumn{4}{|c|}{ Forests } \\
\hline & $\begin{array}{l}\text { Primary } \\
\text { (PMF) }\end{array}$ & $\begin{array}{l}\text { Early successional } \\
\text { (ESF) }\end{array}$ & $\begin{array}{l}\text { Mid-successional } \\
\text { (MSF) }\end{array}$ & $\begin{array}{l}\text { Late-successional } \\
\text { (LSF) }\end{array}$ \\
\hline \multicolumn{5}{|l|}{ Rainy season (June-October) } \\
\hline \multirow{2}{*}{$\begin{array}{ll} & \left(\mathrm{mg} \mathrm{P} \mathrm{g}^{-1}\right) \\
& \left(\mathrm{kg} \mathrm{P} \mathrm{ha}^{-1}\right)\end{array}$} & $0.99(0.06) \mathrm{A}$ & $0.73(0.07) \mathrm{A}$ & $0.63(0.05) \mathrm{A}$ & $0.98(0.06) \mathrm{A}$ \\
\hline & $1.148(0.129) \mathrm{B}$ & $1.956(0.229) \mathrm{A}$ & $1.336(0.109) \mathrm{B}$ & $1.400(0.101) \mathrm{B}$ \\
\hline \multicolumn{5}{|l|}{ Dry season (November-May) } \\
\hline $\begin{array}{l}\left(\mathrm{mg} \mathrm{P} \mathrm{g}^{-1}\right) \\
\left(\mathrm{kg} \mathrm{P} \mathrm{ha}^{-1}\right)\end{array}$ & $2.678(0.167) \mathrm{A}$ & $1.632(0.130) \mathrm{A}$ & $2.440(0.211) \mathrm{A}$ & $1.953(0.189) \mathrm{A}$ \\
\hline \multicolumn{5}{|l|}{ Annual } \\
\hline Dry weight $\left(\mathrm{Mg}\right.$ dry matter $\left.\mathrm{ha}^{-1} \mathrm{y}^{-1}\right)$ & $4.17(0.48) b$ & $5.88(0.28) \mathrm{a}$ & $5.62(0.23) \mathrm{a}$ & $3.77(0.45) b$ \\
\hline \multirow{2}{*}{$\begin{array}{l}\mathrm{P} \quad\left(\mathrm{mg} \mathrm{P} \mathrm{g}^{-1}\right) \\
\left(\mathrm{kg} \mathrm{P} \mathrm{ha}^{-1} \mathrm{y}^{-1}\right)\end{array}$} & $0.92(0.06) \mathrm{a}$ & $0.63(0.07) b$ & $0.67(0.06) \mathrm{b}$ & $0.900 .06) \mathrm{a}$ \\
\hline & $3.826(0.263) \mathrm{a}$ & $3.588(0.329) \mathrm{a}$ & $3.776(0.288) \mathrm{a}$ & $3.393(0.367) \mathrm{a}$ \\
\hline
\end{tabular}

Different uppercase letters indicate means are significantly different $(P<0.05)$ when testing differences in litterfall mass, $\mathrm{P}$ content in litterfall, or flux between rainy and dry seasons within a forest type; whereas different lower case letters indicate means are significantly different $(P<0.05)$ when testing for differences in annual total litterfall mass, $\mathrm{P}$ content in litterfall, or flux among forest type.

(September 2001) and the dry season (March 2002). In each sampling date, eight soil cores $(8 \mathrm{~cm} \times 20 \mathrm{~cm}$ depth) were collected randomly from each one of the plots, mixed in the field and stored at $4{ }^{\circ} \mathrm{C}$ for up to $72 \mathrm{~h}$ until processing. In the laboratory, the composite soil samples were hand-homogenized and sieved (2-mm mesh) and a sub-sample dried at constant weight for moisture determination. The remaining soil was used to measure concentrations of $\mathrm{P}$ by soil fractionation.

Phosphorus concentrations were determined using a modified Hedley soil P-fractionation method (Hedley et al., 1982). The fractionation scheme included: (1) extraction of readily solubilized Pinorganic $(\mathrm{Pi})$, and readily mineralized $\mathrm{P}$-organic $(\mathrm{Po})$ with $0.5 \mathrm{M}$ $\mathrm{NaHCO}_{3}$, adjusted to an $8.5 \mathrm{pH}$; and (2) extraction of Pi and Po chemisorbed to $\mathrm{Fe}$ and $\mathrm{Al}$ surfaces in the soil, partially stabilized as soil organic matter, or immobilized within microorganisms with $0.2 \mathrm{M} \mathrm{NaOH}$ (Cross and Schlesinger, 1995). A second subsample was extracted with hot concentrated $\mathrm{H}_{2} \mathrm{SO}_{4}$ plus a $\mathrm{H}_{2} \mathrm{O}_{2}$ solution (total $\mathrm{P}$ ).

For each composite sample, $0.5 \mathrm{~g}$ of air-dried soil was placed in $50 \mathrm{~cm}^{3}$ centrifuge tubes; $30 \mathrm{~mL}$ of $0.5 \mathrm{M} \mathrm{NaHCO}_{3}$ solution were added to all tubes, shaken for $16 \mathrm{~h}$, and centrifuged at $10000 \mathrm{rpm}$ at $0{ }^{\circ} \mathrm{C}$ for $10 \mathrm{~min}$. The supernatant was filtered. This process was repeated for each extract solution (i.e., bicarbonate and hydroxide extractions). Concentrations of soil total $\mathrm{P}$, bicarbonate-P and hydroxide-P were transformed into area units ( $\mathrm{kg}$ per ha) using bulk density values and the soil volume occupied by rock materials in each plot (Elliot et al., 1999). Soil bulk density was $1.02 \pm 0.02 \mathrm{~g} \mathrm{~cm}^{-3}$ in PMF, $1.00 \pm 0.02 \mathrm{~g} \mathrm{~cm}^{-3}$ in ESF, $1.00 \pm 0.03 \mathrm{~g} \mathrm{~cm}^{-3}$ in MSF, and $0.99 \pm 0.03 \mathrm{~g} \mathrm{~cm}^{-3}$ in LSF.

\subsection{Chemical analysis}

Litterfall and litter samples were oven-dried $\left(60{ }^{\circ} \mathrm{C}\right.$ for $\left.48 \mathrm{~h}\right)$ and ground (40- $\mu \mathrm{m}$ mesh size). Phosphorus content was determined after digestion. $0.5 \mathrm{~g}$ of vegetal material was digested with $7 \mathrm{~mL}$ of concentrated $\mathrm{H}_{2} \mathrm{SO}_{4}, 1.1 \mathrm{~g}$ of digest mixture $\left(\mathrm{K}_{2} \mathrm{SO}_{4}\right.$ and $\left.\mathrm{Cu}_{2} \mathrm{SO}_{4}, 9: 1\right)$, and $3 \mathrm{~mL}$ of $\mathrm{H}_{2} \mathrm{O}_{2}$.

Total $\mathrm{P}$ (Pi plus $\mathrm{Po}$ ) in the $\mathrm{NaHCO}_{3}$, and $\mathrm{NaOH}$ were determined using an acidified $\left(\mathrm{H}_{2} \mathrm{SO}_{4}\right)$, ammonium-persulfate digestion (45 min) in an autoclave. For these fractions, Pi was measured directly on acidified, undigested samples; Po was then calculated by difference (total $\mathrm{P}-\mathrm{Pi}$ ). All extracts were neutralized and diluted, prior to the $\mathrm{P}$ content analysis.

The $\mathrm{P}$ of all solutions and standards was measured colorimetrically using an Auto Analyzer. All chemical determinations were duplicated, rejecting those with a more than $10 \%$ difference among them.

\subsection{Statistical analyses}

The seasonal variations of $\mathrm{P}$ concentrations and fluxes in litterfall and in P concentrations and pools in the forest soil were determined by ANOVA. Also, differences in P concentrations and masses among forest stages were analyzed by ANOVA. The Honest Significant Difference (HSD) test was used when statistical differences $(P<0.05)$ were observed.

\section{RESULTS}

\subsection{Phosphorus cycling in litterfall}

Total annual litterfall was larger in ESF and MSF plots than in PMF and LSF plots (Tab. II). Generally, the seasonal distribution of litterfall showed higher production during the dry period (November to May), and lower rates during the wet season (June to October). However, in ESF plots litterfall was nearly the same in both periods.

Mean annual $\mathrm{P}$ concentration increased with forest age (Tab. II). Although mean values show this effect of forest age on $\mathrm{P}$ content in litterfall, there was an obvious inverse relation between nutrient concentration and litterfall mass. Throughout the forest ages, litterfall P content changed significantly; they reached their minimum values during the dry season, when the amounts of litterfall were higher, and rose during the rainy season. Seasonal patterns of $\mathrm{P}$ content in litterfall varied in terms 
Table III. Means ( \pm standard error) of litter mass, P concentrations, and pools for different seasonally dry tropical forests studied at Sierra de Huautla, Mexico.

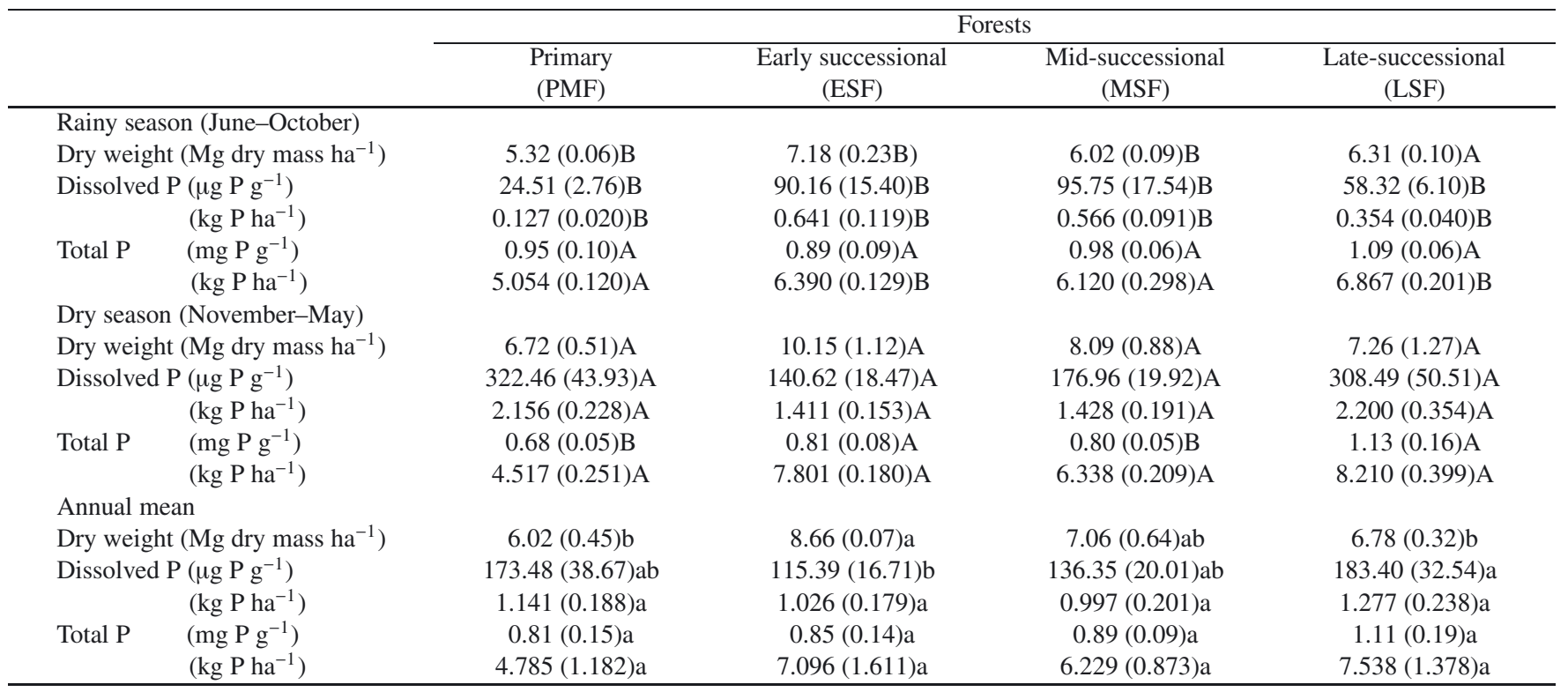

Different uppercase letters indicate means are significantly different $(P<0.05)$ when testing differences in litter mass, litter $\mathrm{P}$ concentration, or pool between rainy and dry seasons within a forest type; whereas different lower case letters indicate means are significantly different $(P<0.05)$ when testing for differences in annual mean of litter mass, litter P concentration, or pool among forest type.

of age. The ESF plots showed the highest decline of $\mathrm{P}$ content in litterfall during the dry season among forests. In contrast, there was no seasonal pattern of $\mathrm{P}$ content in litterfall in MSF plots.

Total annual $\mathrm{P}$ flux in litterfall showed little variation among the forests, and no significant difference was detected among forest ages (Tab. II). The amounts of P fluxes from vegetation to the forest floor were higher in the dry season than in the rainy season (by a factor of 2 in the case of PMF, by 0.8 in the case of MSF, and by 0.4 in the case of LSF). However, no significant difference was detected in litterfall $P$ fluxes between seasons in ESF plots.

\subsection{Pools in forest litter}

Through forest ages, mean annual litter was significantly higher in ESF than in PMF, and LSF (Tab. III). Litter mass in MSF constituted an intermediate group. Litter annual mean was higher than litterfall irrespective of forest age (by $44 \%$ in the case of primary forest; and 47,26 , and $80 \%$ in the cases of ESF, MSF and LSF, respectively). During the dry season, the accumulation of litter on the PMF, ESF and MSF forest floor was higher than in the rainy season. Mean annual litter mass during the November-May period (dry season) increased between 26 and $41 \%$ with respect to the values registered in June to October (rainy season). Although in LSF litter mass increased by about $15 \%$ during the dry season with respect to the rainy season, this tendency was not significant $(P>0.05)$.

The gradient of $\mathrm{P}$ content in litterfall through forest ages was not observed in litter for total P (Tab. III). Phosphorus con- centration on PMF and MSF forest floor fluctuated throughout the year registering a peak in the rainy season. In contrast, the rainfall seasonal pattern did not affect the litter $\mathrm{P}$ concentration of ESF and LSF.

Relative to the litter total $\mathrm{P}$ concentration the annual mean concentration of dissolved $\mathrm{P}$ increased with forest age from $13 \%$ in ESF, to $15 \%$ in MSF, and $21 \%$ in PMF (Tab. III). Dissolved $\mathrm{P}$ concentration was greater in LSF than in ESF; PMF and MSF constituted an intermediate group, with no significant differences with the previous two forest age types. Seasonal patterns in dissolved $\mathrm{P}$ were very consistent through forest ages. Litter dissolved $P$ concentrations increased in the dry season in relation to the rainy season in all forest ages. There were strong successional patterns of relative and absolute increases in dissolved $\mathrm{P}$ concentration during the dry season, following the direction $\mathrm{ESF}<\mathrm{MSF}<\mathrm{LSF}<\mathrm{PMF}$.

The annual mean of $\mathrm{P}$ pools (total and dissolved) in the litter layer did not vary through forest ages (Tab. III). Total P pools on the litter floor were more numerous during the dry season than in the rainy season in ESF and LSF. However, there were no significant differences in $\mathrm{P}$ pools in PMF and MSF plots from one season to another. In contrast, throughout forest ages dissolved $\mathrm{P}$ was more abundant in the dry season than in the rainy season.

\subsection{Phosphorus pools in soil}

Contrary to what was expected, the successional stage did not affect the total soil $\mathrm{P}$ pool (Tab. IV). And yet, there were significant differences in bicarbonate $\mathrm{P}$ pools between 
Table IV. Means ( \pm standard error) of soil P pools $\left(\mathrm{kg} \mathrm{P} \mathrm{ha}^{-1}\right)$ for different seasonally dry tropical forests studied at Sierra de Huautla, Mexico.

\begin{tabular}{|c|c|c|c|c|}
\hline & \multicolumn{3}{|c|}{ Forests } & \multirow[b]{2}{*}{$\begin{array}{c}\text { Late-successional } \\
\text { (LSF) }\end{array}$} \\
\hline & $\begin{array}{l}\text { Primary } \\
(\mathrm{PMF})\end{array}$ & $\begin{array}{c}\text { Early successional } \\
\text { (ESF) }\end{array}$ & $\begin{array}{c}\text { Mid-successional } \\
\text { (MSF) }\end{array}$ & \\
\hline \multicolumn{5}{|l|}{ Rainy season (September) } \\
\hline $\mathrm{NaHCO}_{3} \mathrm{Po}$ & 16.81 (1.79)A & $8.57(2.34) \mathrm{B}$ & $8.66(3.24) \mathrm{B}$ & 11.79 (2.17)A \\
\hline $\mathrm{NaOH} \mathrm{Pi}$ & $3.19(0.45) \mathrm{A}$ & 3.57 (1.19)A & $2.83(0.81) \mathrm{B}$ & $3.95(0.35) \mathrm{A}$ \\
\hline \multicolumn{5}{|l|}{ Dry season (March) } \\
\hline $\mathrm{NaHCO}_{3} \mathrm{Pi}$ & $1.62(0.80) \mathrm{B}$ & $1.26(0.22) \mathrm{A}$ & $0.19(0.03) \mathrm{B}$ & $0.48(0.25) \mathrm{B}$ \\
\hline $\mathrm{NaHCO}_{3} \mathrm{Po}$ & $17.20(1.43) \mathrm{A}$ & $15.65(1.59) \mathrm{A}$ & 16.03 (1.78)A & 16.07 (1.48)A \\
\hline $\mathrm{NaOH} \mathrm{Pi}$ & $6.30(1.58) \mathrm{A}$ & $5.18(0.43) \mathrm{A}$ & $5.00(0.23) \mathrm{A}$ & $4.91(0.54) \mathrm{A}$ \\
\hline $\mathrm{NaOH} \mathrm{Po}$ & $38.67(4.25) \mathrm{A}$ & 36.65 (4.93)A & $49.08(3.07) \mathrm{A}$ & $43.10(3.93) \mathrm{A}$ \\
\hline $\mathrm{NaOH} \mathrm{Pi}$ & $5.75(0.57) \mathrm{a}$ & $4.38(0.57) b$ & $3.92(0.56) \mathrm{b}$ & $4.43(0.44) b$ \\
\hline $\mathrm{NaOH} \mathrm{Po}$ & $41.55(4.12) \mathrm{ab}$ & $32.55(3.41) \mathrm{b}$ & $43.78(5.29) \mathrm{ab}$ & $45.66(4.01) \mathrm{a}$ \\
\hline Total P & $945.1(72.3) \mathrm{a}$ & $805.9(59.1) \mathrm{a}$ & $840.4(81.1) \mathrm{a}$ & $876.2(103.0) \mathrm{a}$ \\
\hline
\end{tabular}

Different uppercase letters indicate means are significantly different $(P<0.05)$ when testing differences in each $\mathrm{P}$ fraction or total $\mathrm{P}$ pools between rainy and dry seasons within a forest type; whereas different lower case letters indicate means are significantly different $(P<0.05)$ when testing for differences in annual mean of each $\mathrm{P}$ fraction or total $\mathrm{P}$ pools among forest type.

the PMF and successional forests (see annual mean). Midsuccessional forest sites had the lowest bicarbonate Pi pools, whereas PMF sites had the greatest pools. The mean of bicarbonate Po pools was the highest in PMF soils and the lowest in ESF. Hydroxide P pools varied significantly among forests, but changes were not consistently related to succession stages. PMF soils had the highest hydroxide Pi pool in relation to soils from secondary forests. In contrast, LSF had the highest hydroxide Po pool, and the lowest pool was detected in ESF. PMF and MSF soils constituted an intermediate group that did not significantly differ from ESF and LSF soils.

The sampling date did not affect the total soil $\mathrm{P}$ pool (Tab. IV). On the other hand, the bicarbonate pools (inorganic and organic) in soils differed between seasons, depending on the successional stage. PMF, MSF and LSF soils had a bicarbonate $\mathrm{Pi}$ (available $\mathrm{P}$ ) pool approximately three times larger in the dry season than in the rainy season. In contrast, bicarbonate Po pools from soils of ESF and MSF were greater in the rainy season than in the dry season. Bicarbonate Po pools in PMF and MSF soils did not significantly change with sampling dates. The hydroxide Pi pool increased in the dry season; but differences between sampling dates were significant only in the case of MSF soils. Finally, seasonal rainfall did not affect the hydroxide Po pool in the soils.

\section{DISCUSSION}

The internal sub-cycling processes, mainly the aboveground $\mathrm{P}$ return from vegetation to the soil, control $\mathrm{P}$ dynam- ics in SDTFs, according to Campo et al. (2001). The amount of litterfall P flux in primary forest is greater than in SDTFs in an infertile site in Puerto Rico $\left(0.79 \mathrm{~kg} \mathrm{P} \mathrm{ha}^{-1} \mathrm{y}^{-1}\right.$; Lugo and Murphy, 1986), but is closer to the lower end of the global range excluding Puerto Rico sites (3.66 to $14.45 \mathrm{~kg} \mathrm{P} \mathrm{ha}^{-1} \mathrm{y}^{-1}$; Campo et al., 2001; Read and Lawrence, 2003). By comparing $\mathrm{P}$ content in litterfall among forest sites, the primary forests of Morelos recorded the second highest values among several SDTFs (0.2 to $1.1 \mathrm{mg} \mathrm{P} \mathrm{g}^{-1}$; Campo et al., 2001; Read and Lawrence, 2003). Annual mean residence times (MRT; calculated as the ratio of the litter mass or P pool to the annual litterfall production or P flux in the litterfall; Waring and Running, 1998) (calculated from Tabs. II and III; $1.2 \mathrm{y}$ for P and $1.4 \mathrm{y}$ for organic matter) suggest a slight prevalence of plant uptake over P immobilization (according to Vogt et al., 1986). Both the high concentration of $\mathrm{P}$ in the litterfall and the relatively low MRT in this study suggest that the Morelos mature forest may not be limited by $\mathrm{P}$ availability. This hypothesis could be verified with a study of primary production at ecosystem level, analyzing the forest responses to a nutrient addition (i.e., to a release from nutrient limitation; see Harrington et al., 2001).

The expected pattern of increasing P flux in litterfall following an earlier use of the soil by agriculture did not occur. Phosphorus return to soil from forest litterfall was unaffected by the successional stage of the forest. In contrast, $\mathrm{P}$ concentration in litterfall increased significantly with forest age, suggesting that $\mathrm{P}$ is cycled more efficiently (by a higher nutrient resorption proficiency, sensu Killingbeck, 1996), where soil P is less abundant (Tab. IV). Hence, $\mathrm{P}$ content in litterfall is likely 
driven by soil $\mathrm{P}$ availability. On the other hand, the lower $\mathrm{P}$ concentration in litterfall than in litter (see Tabs. II and III) suggests there is a slight immobilization of $\mathrm{P}$ in the floor litter of the secondary forests studied. We can not determine whether such P immobilization in the forest floor resulted from the dissolved nutrient accumulation during the dry season (i.e., a consequence of rainless period and then no leaching), or if it reflects the high levels of $\mathrm{P}$ immobilization during the dry season (an indirect consequence of a decrease in water supply) (Campo et al., 1998; Singh et al., 1989), or both. Clearly, this is an aspect that requires further research, especially on the effects on the decomposition, and the release of nutrients from the litter (see Mo et al., 2008).

Forest litter decomposition has been considered one of the main pathways for nutrient cycling in SDTF ecosystems (Kundu, 1990). Total P in the forest litter of Morelos (primary and secondary forests) increases during the dry season, possibly as a result of reduced microbial activity and leaching (Saynes et al., 2005), leading to a larger amount of litter mass. The extended dry season, with reduced leaching and plant uptake, may also promote the accretion of dissolved $\mathrm{P}$ pools in the forest floor of all forests. Results showed that dissolved P in dry-season litter represents as much as $56 \%$ of the litterfall P returning to the soil in PMF, and 39, 38 and $65 \%$ of those return in ESF, MSF and LSF, respectively (Tabs. II and III). Additionally, differences in litter dissolved-P pools due to forest age were registered during the rainy season. Above all, these results indicate the importance of dissolved $\mathrm{P}$ accumulation on the forest floor for the supply of $\mathrm{P}$ to plants, and suggest that $\mathrm{P}$ dynamics and constraints in the forest floor may be different between younger secondary forests and PMF. Results from the LSF plots suggest that the recovery of $\mathrm{P}$ dynamics processes in the seasonally tropical dry forest floor of Morelos occur during ca. 60 years of secondary succession. This hypothesis needs to consider site-specific differences in $\mathrm{P}$ cycling processes.

The massive uptake of nutrients by vegetation from the soil during the growing season diminishes soil $\mathrm{P}$ during the rainy season (Campo et al., 1998). There is consensus that the $P$ removed by bicarbonate is available to plants in the short term, i.e., in the course of the growing season (Cross and Schlesinger, 1995). According to our data, soil P bicarbonate pools during the rainy season were lower than in the dry season in sites with low P labile pools (i.e., in ESF and MSF). However, seasonal changes in Po bicarbonate in LSF and PMF soils were not significant. Total-labile P soil pools (i.e., inorganic plus organic pools) at $20 \mathrm{~cm}$ deep during the dry season were largely greater than the $\mathrm{P}$ flux from litterfall across forests (by a factor of 5, 3.8, 3.4 and 4.4 times in the case of PMF, ESF, MSF, and LSF, respectively). Campo et al. (2001) estimated the aboveground litterfall P flux accounts for more than $90 \%$ of the aboveground annual P loss in a mature SDTF of the Pacific coast of Mexico, and the belowground P requirements by plants could be approximately equal to those aboveground. Thus, the results obtained in Morelos give evidence that $\mathrm{P}$ requirements in the short term of the primary and secondary forests included in our study are sufficiently met by $\mathrm{P}$ mineralization from the forest floor and soil labile pools. Interestingly, these results did not differ from the findings by
Johnson et al. (2003), who found evidence that Hedley-labile $P$ pools in soils appeared to be several times larger than annual requirement of $\mathrm{P}$ in humid tropical forests, even though many tropical forests appeared to be P limited (Vitousek, 1984). On the other hand, the sufficient $\mathrm{P}$ availability in the soil could be maintained during succession (despite the expected nutrient accumulation in forest biomass during secondary succession, see Brown and Lugo, 1990) by a substantial cycling of Po and Pi from Ca compounds, as suggested by Richter et al. (2006). Clearly, a further understanding of P biogeochemical processes in forest soils is required, especially focused on the relationship between operationally defined plant-available $\mathrm{P}$ and plant $P$ nutrition.

This study on the consequences of aging of the secondary forest following the cessation of agricultural practices in Morelos, resulting in soil and forest function changes, comes to the conclusion that the $\mathrm{P}$ sub-cycle of the ecosystem studied depends on the successional stage of the forest. On the other hand, results have evidenced that $\mathrm{P}$ dynamics is strongly influenced by the seasonal rainfall pattern. Also, the accumulation of dissolved $\mathrm{P}$ in the forest floor during the rainless period represents a potential source of $\mathrm{P}$ for these ecosystems when the rainy season starts. These findings have important implications for modeling a plant-available $\mathrm{P}$ in seasonally dry tropical forests.

Acknowledgements: We thank J. Gallardo for comments on earlier versions of this manuscript; E. Solís for assistance with laboratory analysis; O. Dorado, D. Valenzuela and A. Mata for their logistical help in the land. We also thank the critical and insightful comments of the editor and two anonymous reviewers, who helped us considerably to improve the manuscript for publication. This work was funded by the Universidad Nacional Autónoma de México (DGAPA) under the Grant N-31954.

\section{REFERENCES}

Brown S. and Lugo A.E., 1990. Tropical secondary forests. J. Trop. Ecol. 6: $1-32$.

Campo J. and Dirzo R., 2003. Leaf quality and herbivory responses to soil nutrient addition in secondary tropical dry forests of Yucatán, Mexico. J. Trop. Ecol. 19: 525-530.

Campo J. and Vázquez-Yanes C., 2004. Effects of nutrient limitation on aboveground carbon dynamics during tropical dry forest regeneration in Yucatán, Mexico. Ecosystems 7: 311-319.

Campo J., Jaramillo V.J., and Maass J.M., 1998. Pulses of soil phosphorus availability in a Mexican tropical dry forest: effects of seasonality and level of wetting. Oecologia 115: 167-172.

Campo J., Maass J.M., Jaramillo V.J., and Martínez-Yrízar A., 2000. Calcium, potassium, and magnesium cycling in a Mexican tropical dry forest ecosystem. Biogeochemistry 49: 21-36.

Campo J., Maass M., Jaramillo V.J., Martínez-Yrízar A., and Sarukhán J., 2001. Phosphorus cycling in a Mexican tropical dry forest ecosystem. Biogeochemistry 53: 161-179.

Campo J., Valencia M.G., and Solís E., 2007. Litter N and P dynamics in two secondary tropical dry forests after relaxation of nutrient availability constraints. For. Ecol. Manage. 252: 33-40. 
Cárdenas I. and Campo J., 2007. Foliar nitrogen and phosphorus resorption and decomposition in the nitrogen-fixing tree Lysiloma microphyllum in primary and secondary seasonally dry tropical forests in Mexico. J. Trop. Ecol. 23: 107-113.

Cross A.F. and Schlesinger W.H., 1995. A literature review and evaluation of the Hedley fractionation: applications to the biogeochemical cycle of soil phosphorus in natural ecosystems. Geoderma 64: 197-214.

Elliot E.T., Heil J.W., Kelly E.F., and Monger H.C., 1999. Soil structural and other physical properties. In: Robertson G.P., Coleman D.C., Bledsoe C.S. and Sollins P. (Eds.), Standard soil methods for long-term ecological research, Oxford University Press, New York, pp. 74-85.

Giardina C.P., Sanford R.L. Jr, and Dockersmith I.C., 2000. Changes in soil phosphorus and nitrogen during slash-and-burn clearing of a dry tropical forest. Soil Sci. Soc. Am. J. 64: 399-405.

Harrington R.A., Fownes J.H., and Vitousek P.M., 2001. Production and resource use efficiencies in $\mathrm{N}$ - and P-limited tropical forests: a comparison of responses to long-term fertilization. Ecosystems 4: 646-657.

Hedley M.J., Steward J.W.B., and Chauhan B.S., 1982. Changes in inorganic and organic soil phosphorus fractions induced by cultivation practices and by laboratory incubations. Soil Sci. Soc. Am. J. 46: 970-976.

Johnson A.H., Frizano J., and Vann D.R., 2003. Biogeochemical implications of labile phosphorus in forests soil determined by the Hedley fractionation procedure. Oecologia 135: 487-499.

Killingbeck K.T., 1996. Nutrients in senesced leaves: keys to the search for potential resorption and resorption proficiency. Ecology 77: $1716-1727$.

Kundu D.K., 1990. Tropical leaf-litter nutrients. Nature 344: 203.

Lugo A.E. and Murphy P.G., 1986. Nutrient dynamics of a Puerto Rican subtropical dry forest. J. Trop. Ecol. 2: 55-72.

Maass J.M., 1995. Conversion of tropical dry forest to pasture and agriculture. In: Bullock S.H., Mooney H.A., and Medina E. (Eds.), Seasonally dry tropical forests, Cambridge University Press, Cambridge, pp. 399-422.
McLaughlan K., 2006. The nature and longevity of agricultural impacts on soil carbon and nutrients: a review. Ecosystems 9: 1364-1382.

Mo J., Fang H., Zhu W., Zhou G., Lu X., and Fang Y., 2008. Decomposition responses of pine (Pinus masoniana) needles with two different nutrient-status to $\mathrm{N}$ deposition in a tropical pine plantation in southern China. Ann. For. Sci. 65: 405.

Mooney H.A., Bullock S.H., and Medina E., 1995. Introduction. In: Bullock S.H., Mooney H.A., and Medina E. (Eds.), Seasonally Dry Tropical Forests, Cambridge University Press, Cambridge, pp. 1-8.

Murphy P.G. and Lugo A.E., 1986. Ecology of tropical dry forest. Annu. Rev. Ecol. Syst. 17: 67-88.

Read L. and Lawrence D., 2003. Litter nutrient dynamics during succession in dry tropical forests of the Yucatan: regional and seasonal effects. Ecosystems 6: 747-761.

Richter D.D., Allen H.L., Li J., Markewitz D., and Raikes J., 2006. Bioavailability of slowly cycling soil phosphorus: major restructuring of soil $\mathrm{P}$ fractions over four decades in an aggrading forest. Oecologia 150: 259-271.

Saynes V., Hidalgo C., Etchevers J.D., and Campo J.E., 2005. Soil C and $\mathrm{N}$ dynamics in primary and secondary seasonally dry tropical forests in Mexico. Appl. Soil Ecol. 29: 282-289.

Singh J.S., Raghubanshi A.S., Singh R.S., and Srivastava S.C., 1989. Microbial biomass acts as a source of plant nutrients in dry tropical forest and savanna. Nature 338: 499-500.

Solís E. and Campo J., 2004. Soil N and P dynamics in two secondary tropical dry forests after fertilization. For. Ecol. Manage. 195: 409-418.

Vitousek P.M., 1984. Litterfall, nutrient cycling, and nutrient limitation in tropical forests. Ecology 65: 285-298.

Vogt K.A., Grier C.C., and Vogt D.J., 1986. Production, turnover, and nutrient dynamics of aboveground and belowground detritus of world forests. Adv. Ecol. Res. 15: 303-377.

Waring R.H. and Running S.W., 1998. Forest ecosystems: Analysis at multiple scales, Academic Press, San Diego, 370 p. 